\title{
部分床義歯離脱時における維持霜の負荷に関する研究
}

\author{
八川 昌人
}

\section{Stress Analysis of Abutment Teeth on Removal Moment of R.P.D.'s}

\author{
Masato Hachikawa
}

Abstract : During function, every R.P.D. shows denture movement that is converted into stress to the abutments.

Our two investigations revealed that guide surfaces on the retainers was effective in reducing the stress.

In R.P.D. treatment, many different designs of clasp systems have been used with less consideration of this guiding function.

In this study, four types of clasps, Aker's clasp, Krol R.P.D., Kratochvil R.P.D. and the Crown Ledge preparation, having different guide surfaces were examined to measure the mobility of abutments under the pull out force.

Metal frame dentures were provided in order to measure these movement with electronic sensor.

Each retainer had interchangeable feature to fasilitate the investigation.

The following results were obtained,

1. Aker's clasp showed small amplitude with high frequency during removal periods.

2. Both R.P.I. clasps give only small vibration when the path of removal is adjusted. To get this direction is difficult.

3. Guide surface of Crown Ledge clasp is effective in reducing the mobility of abutment tooth.

4. The guiding surface therapy has an effect in reducing the abutment vibration.

Key words : stress to the abutment, guide surface, the mobility of abutment, removal periods, the path of removal

I. 緒言

部分林義歯装着患者が義歯装着後その装着を中止する
因子としては，種々なものがあげられているが，その中

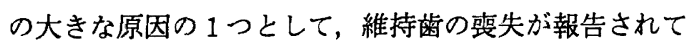
いる1 5).この維持歯の喪失の原因には，通常部分床義 歯の良好な維持安定を確保したいがために, 維持歯に部
昭和大学歯学部第三歯科補緅学教室 (指導 : 芝 炜彦教授) The Third Dept. of Prosthodontics, Faculty of Dentistry
Showa University (Chief : Prof. Akihiko Shiba) 平成元年 11 月 14 日受付 
分床義歯の安定三要素である維持，支持，把持を多く求 め過ぎることに起因すると思われる. そしてその結果, 機能時に生じる種々の義歯の動摇が直接維持歯に集中的 に伝達され, これが維持歯への負担過重を引き起こし, そして維持歯の動摇につながり，最終的には維持齔の衰 失人と導かれていくものといえる ${ }^{6 \sim 8)}$. これら部分床義 歯の維持歯の動摇量の変化と義歯自体の示す動態に関し ては, Bazirgan と Bates ${ }^{9)}$ が報告し, また維持装置の維 持力発現機檴については Steffel ${ }^{10)}$ や Mühleman ${ }^{11)} に$ より報告がされている，筆者は義歯の動摇によって維持 歯へ伝達される上下および水平方向の動きには, 各種維 持装置の有する維持力発現機構の違いが大きく関与して いる可能性があり，そしてこれらの動きはすべて維持歯 に対しては抜去方向への為害作用として働くと考えた.

この為害性を検索するため, まず維持力発現機構の異 なる 5 種類の維持装置を作製し, 口腔内維持歯上で離脱 をくり返し行わせ, 維持歯の水平, 上下の 2 方向の動態 を観察し, 同時に各維持装置が示した維持力の大きさを 測定した. 次に, 比較対照として同一の維持装置を用い て模型上で同様の離脱動態の測定を行い，そのときの模 型上での維持歯の動摇量を測定した. これらの結果, 测 定に用いた 5 種類の維持装置の中では, コーヌスクロー ネのみが, 維持歯の持つ生理的に対応可能な範囲内に収 まることを明らかにした12).

次に, 各種維持装置を長期間使用した際に維持歯に生 じる為害性について検索を行った. 3 種類の異なる維持 装置の逐次交換可能な実験用部分床義歯を作製し, これ を同一口腔内で各々一定期間装着させ，各期間毎の維持 装置により維持歯に蓄積された負荷について, 維持歯の 動摇量を指標として経時的な測定を行った. その結果, 3 種類の維持装置のうちでは, コーヌスクローネが維持 歯にとって蓄積的な為害性においても小さな維持装置で

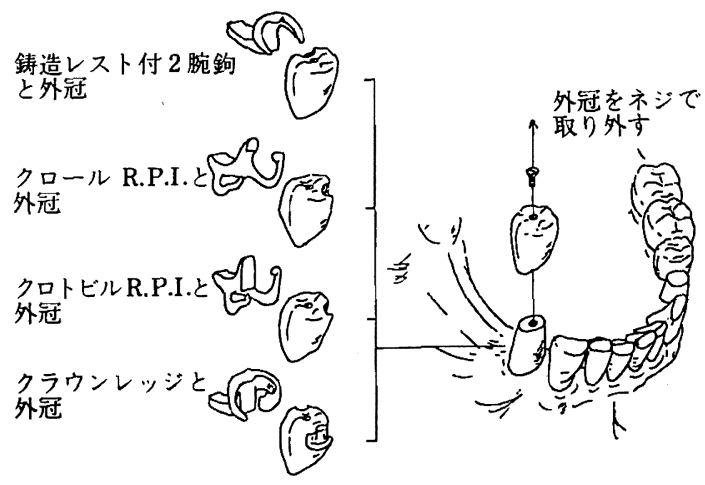

図 1 測定に用いた維持装置
あることが判明した ${ }^{13)}$.そして，これらコーヌスクロー ネの特性はその全周に存在する円周面が, 離脱時にガイ ド面として作用しているためと考えられる.

しかし，今日の日常臨床において部分床義歯の維持装 置として一般に嚬用されているのは，クラスプである.

そこで筆者は, クラスプ維持装置にコーヌスクローネ の特徴である側方への動摇抑制作用があるガイド面を取 り入れることの有效性を検討していく必要性を認め

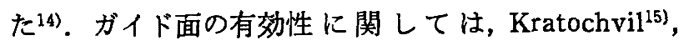
$\mathrm{Krol}^{16)}$ により報告されているが, 彼らの報告は義歯の機

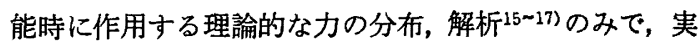
際の臨床的な口腔内での測定報告はなされていない.

そこで, 現在広く用いられている種々の形態の異なる ガイド面機構を有するクラスプ維持装置を，義歯の動摇 抑制が難しい片側遊離端義歯の症例に適応し，各維持装 置の離脱時の維持力および維持歯の動摇量を測定し, 各 維持装置が有するガイド面機構の有効性について検討を 行ったので報告する.

\section{II. 実験材料および方法}

被験者は 60 歳の全身的に健康で下䪽右側第 2 小田 および第 1 ，第 2 大臼歯が久損しており，上䫑対合歯列 は天然歯列である男性を用いた. 維持歯は動摇度 $\mathrm{m}_{1}$ を 示す欠損側に隣接した右側下顎第 1 小臼歯とした.

測定用維持装置には臨床で頻用されている，(1) 鋳造レ スト付き 2 腕鈎, (2) クロール型 R.P.I. クラスプ, (3) ク ロトビル型 R.P.I. クラスプ, (4) クラウンレッジ型クラ スプの 4 種類を用いた. またこれらの間接維持装置の維 持歯として，反対側下䫟右側第 1 小臼歯を用い，(1)〜 (3) の維持装置の測定時には，鋳造レスト付き 2 腕銿を，(4) の維持装置の測定には，クラウンレッジ型クラスプを用 いたが，これらの維持装置は互いに交換し，組合せて装 着出来るように設計した（図 1).

測定用維持装置の製作は，まず左右側第 1 小臼歯にコ ーヌスクローネ用の形成を行い，印象採得後作業用模型 を製作した. その作業用模型上で維持歯の右下第 1 小臼 歯にはテーパー角 $6^{\circ}$, 咬合面上に直径 $0.2 \mathrm{~mm}$ のネジの 雌部を備え，さらに煩側および舌側両歯肉側縁上部に小 さな凸部を有するコーヌス内冠部をワックスアップし， 鋳造作製した. その内冠歯肉縁上部に幅 $1 \mathrm{~mm}$, 厚さ 0.5 $\mathrm{mm}$ のリング状で，かつ煩側部分に煩側方向へ約 $2 \mathrm{~mm}$ 延長した水平突起部を有する装置をワックスアップ，鋳 造して作製した. このリング状の装置は内冠部の煩舌側 


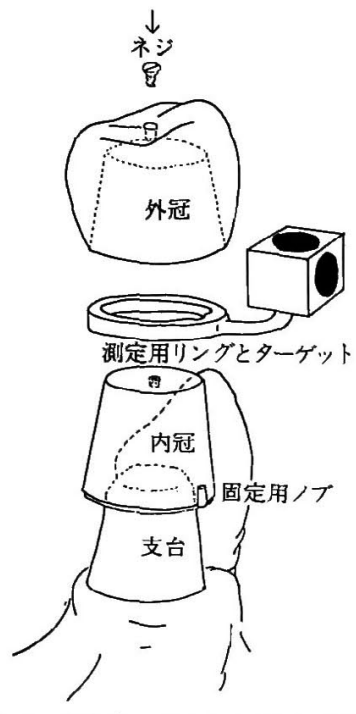

図 2 被験歯の支台と内外冠の関倸

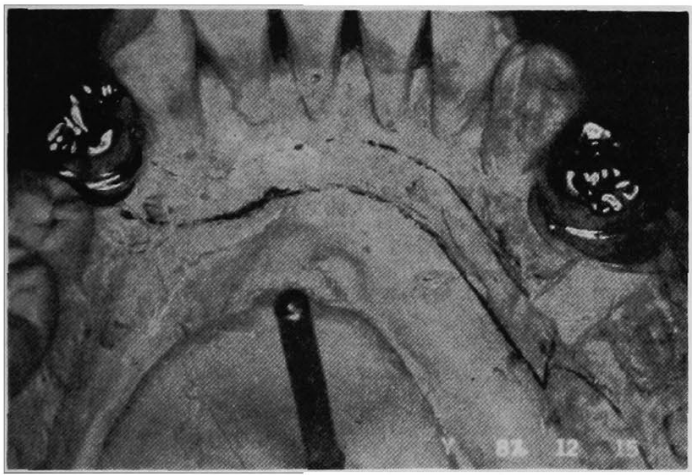

図 3 両維持歯用外冠の作業模型上での位置関係 (クラウ ンレッジ型の測定用外冠を模型上仁装着した場合）

部の突起と嵌合し，動摇測定の際に維持歯と一体化して 固定することが出来, また煩側へ延長した水平突起部は 測定用ターゲットを固定出来る構造とした（図 2).

各測定用クラスプは，まず種々の外冠の製作から行っ た. 模型上で内冠とリング状装置を一体にして装着した のち, その上から各々の測定用クラスプに必要な外冠を 4 種類ワックスアップし，鋳造製作した。なお，これら 各外冠上の咬合面には内冠部の雙部に合わせて小穴をあ けネジにて内冠部と外冠部を一体化出来了形態にし た. また, 間接維持装置の左側第 1 小臼歯にはテーパー 角 $6^{\circ}$ の内冠を作製した. そしてこの内冠上で, 必要な 間接維持装置が適合する外冠として鋳造 2 腕銁用とクラ ウンレッジ型クラスプ用の 2 種類の外冠を作製した. こ の間接維持装置は仮着用セメントにて合着して測定に用

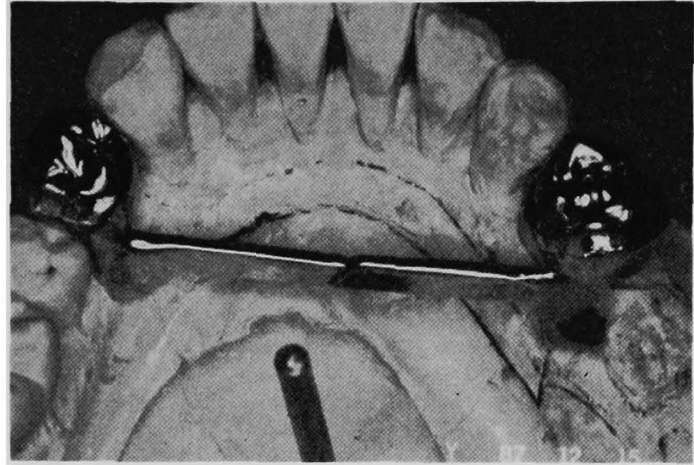

图 4 模型上で両外冠に測定用維持装固を装着した状態

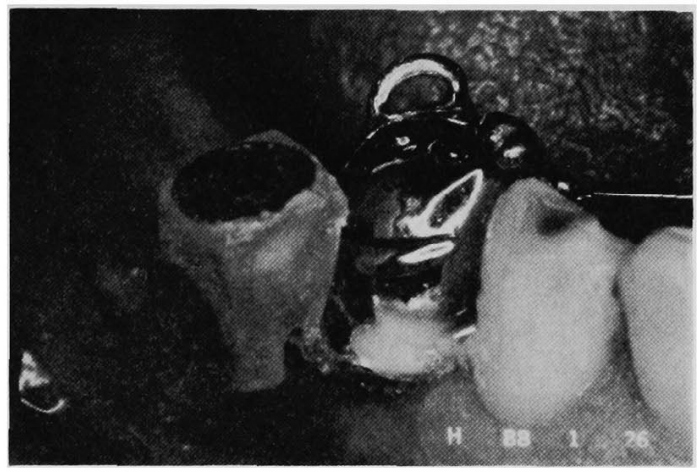

图 5 口腔内で被験歯に測定用ターゲットおよび維持装置 を装着した状態

いるので，ネジ固定用装置は付与しない形態とした（図 $3)$.

各々の外冠上で，測定用維持装置を 4 種類，間接維持 装置用を 2 種類，合計 6 個の維持装置を作製したが，す べての維持装置には舌側方向に突出した脚部を持ち, 左 右の直接維持装置と閒接維持装置を互いに組合せ, 両者 を常温重合レジンにより連結一体化出来る構造とした. なお，全装置は $12 \%$ 金銀パラジウム合金にて製作した (図 4).

測定前準備として, 左右両支台歯に各々の内冠をセメ ント合着し，維持歯には測定用のリングを内冠上に装着 し，その上から各外冠を各回ごとにネジ止めを行い，各 測定維持装置を装着した. 一方間接維持装置用の左側第 1 小臼歯には仮着用セメントにて，外冠を装着し，その 上から間接維持装置を装着させたのち, 両者の維持装置 から出ている脚部を常温重合レジンを用いて舌側中央部 で固定し，測定装置とした，そしてこの両維持装置の有 部に設けたループの両方に糸を通し，一体化した測定装 置を両維持装置の着脱方向に合わせて離脱させることが 


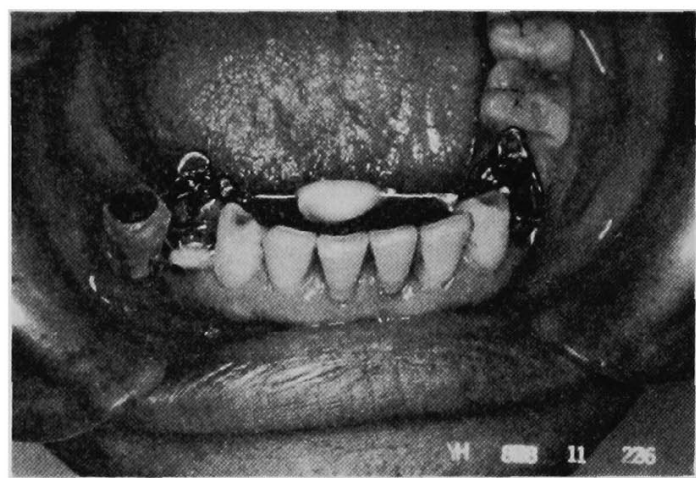

図 6 口腔内で測定用装置を装着した状態

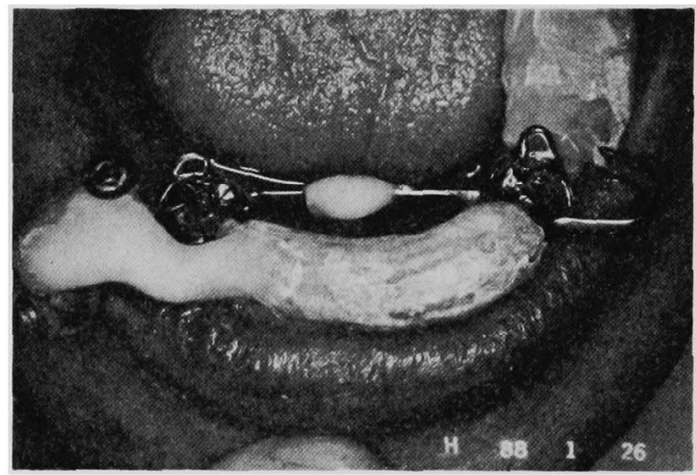

図 7 測定用シーネを他の歯牙上に装着した状態

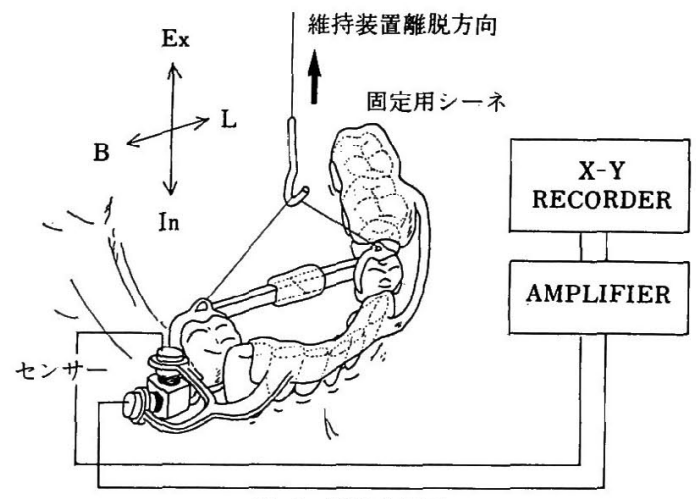

図 8 测定全体図

可能な形態とした（図 5,6 ).

また, 測定用リング上の突起部分には渦電流発生用の ターゲットを固定した. これと対する 2 個の動摇測定セ ンサーは，基準点として固定化させるために，下䪽の前 歯部掞よび左側臼歯部咬合面上に測定時装着したレジン シーネから，維持歯方向に伸ばした腕の先端で瓦いに直 交する方向にて固定した（図 7,8）.

測定は，各装置を装着後一体化した装置上に設けたル

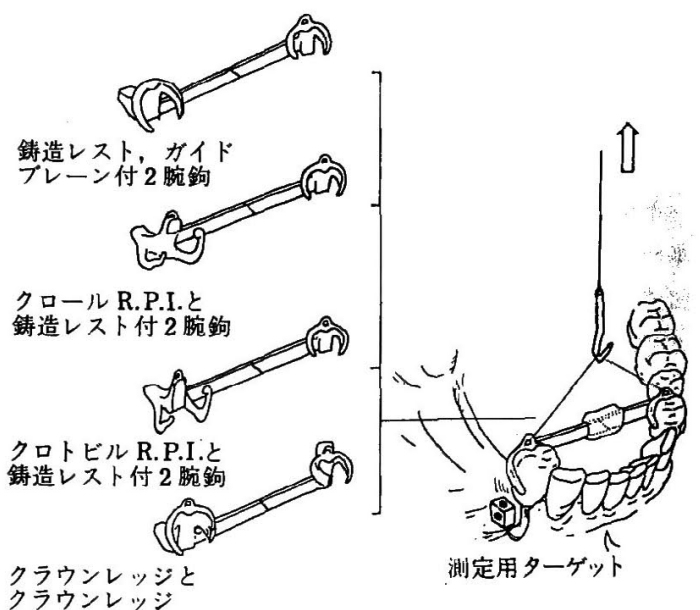

図 9 実験装置の概略

（測定に用いた 4 種の維持装置）

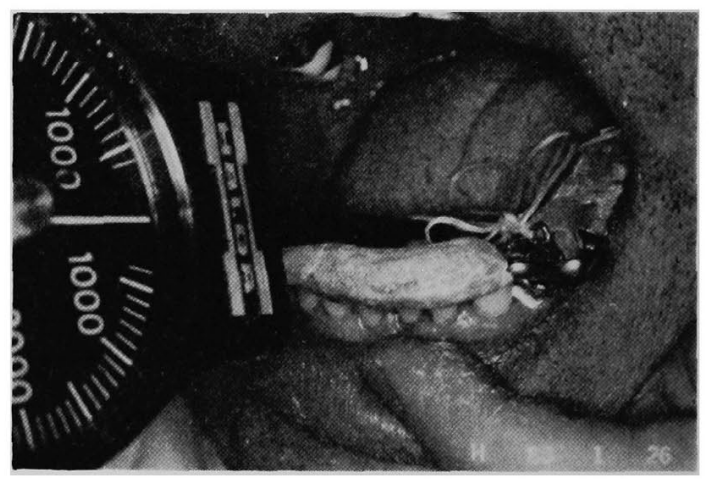

図 10 口腔内での測定

ープに牵引用の糸を通して維持装置全体を牽引し，維持 装置が離脱の際に生じる維持歯の煩舌側方向, 上下方向 の動摇量を非接触センサーによって各々 3 回ずつ測定を 行い, X-Y レコーダ上に記録した. また，同時に各々の 維持装置の発現した維持力についても測定を行った（図 9, 10).

比較対照として，疑似模型を用いて同様な測定を行っ た. 疑似模型はシリコーン印象材を人工歯根膜材料とし て用い, 欠損様式は口腔内と同一な形態とした. 模型上 での測定は口腔内と同一の測定装置を用いて行った. な お，測定に際しては，測定維持装置全体の着脱方向をよ り正確に規定するため, サーベイヤーの雲台上で模型全 体を固定して行った，模型上での維持歯の測定も，口腔 内と同様に離脱を各維持装置別に 3 回ずっ行った（図 11). 


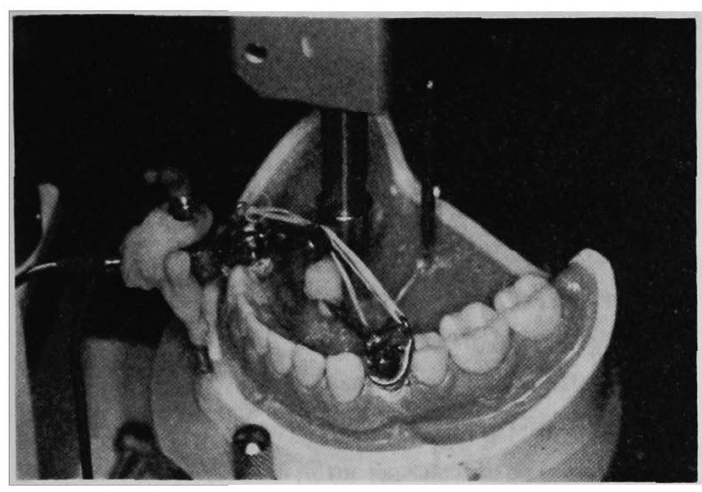

図 11 模型上での測定

\section{III. 実験結果}

\section{1. 離脱時の各維持装置が口腔内およひ模型上の維持 画に与える動摇波形}

各維持装置が離脱までに与えた動摇波形の特色を以下 に示した.

1）鋳造レスト付き 2 腕鉤

離脱時, 維持歯が示した代表的な 2 次元移動波形図を 図 12 に示した. 波形図では維持装置の引き上げ開始 と 同時に鈎先による 5〜10 $\mu$ の微細動を示しながら全体に は大きな波動を示す二重構造の波形を示した. 維持力の 大小に拘わらず, 維持歯は微細な運動をくり返しなが ら，歯全体としては一度沈下し，その後浮上するという 動きの過程において，大きなそして鋭い振幅を示した軌 跡を描きながら煩側に $100 〜 150 \mu$ の振幅を示した. そ の中には維持歯が一部回転および上下運動をしている波 形が認められた. この大きな方の振動の振幅幅は維持力 の大きさと正の相関があった.

2) クロール R.P.I. 型クラスプ

離脱時, 維持歯が示した代表的な 2 次元移動波形図を 図 13 に示した. 維持歯は I バーの維持力の作用してい る間は，維持力の発現が增大するにしたがい煩側方向へ 約 $60 \mu$ 傾斜し, そして鉤先の維持力の哇失とほとんど 同時に維持歯は元の垂直方向に復元しようとする動きを 示したが，垂直軸付近まで復元すると急速にその動きは 減少した，維持装置の離脱に伴い，維持歯は星引されて 浮上するが, その全体としての動摇波形は, 大きくそし て単純な波形を示した.

3）クロトピル R.P.I. 型クラスプ

離脱時，維持歯が示した代表的な 2 次元移動波形図を 図 14 に示した. 維持歯は全体的には微細な振動と大き

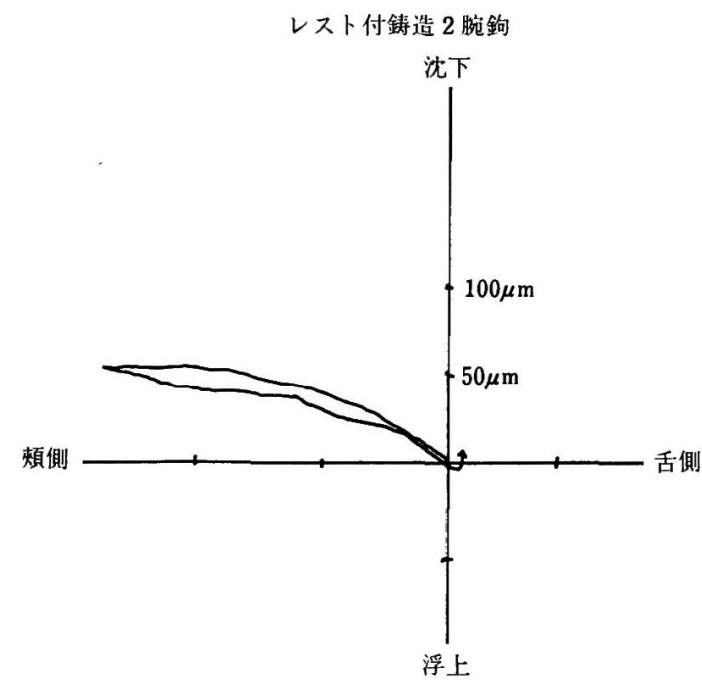

図 12 維持装置離脱時の維持歯の動摇量 （レスト付き鋳造 2 腕鉤）

Krol 型 R.P.I. クラスプ

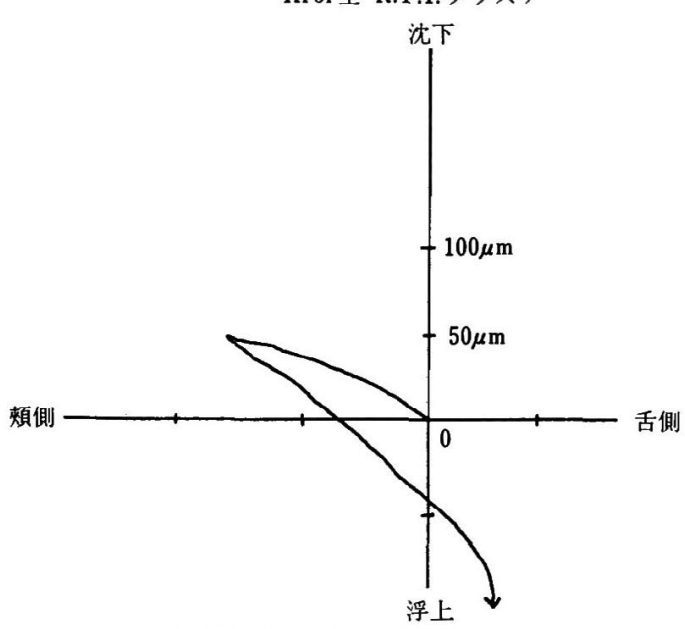

図 13 維持装置離脱時の維持歯の動摇量 (Krol 型 R.P.I. クラスプ)

な振幅との大小 2 つの成分からなる二重構造を示した. I バーがアンダーカット下に存在する閒は，離脱に従い 煩側方向へと傾斜し，維持力が襃失すると同時に維持歯 は歯軸方向へと復元した. これはクロール R.P.I. クラ スプと同様な動きであったが，クロール型のそれと比較 して維持歯の動摇の振幅は小さく，その二重構造の波形 のうち微細な方は激しい動きを示したが，大きな全体の 曲線はクロール型に比べて緩徐な曲線を示した.

4) クラウンレッジクラスプ 
$6-432$

離脱時, 維持歯が示した代表的な 2 次元移動波形図を 図 15 に示した. 維持歯の動摇波形は鋳造ガイドプレー ンレスト付き 2 腕銁と同様な微細な運動を示したが, 煩 側のクラスプの先端の働きにより煩側へ約 $80 \mu$, 舌側人 $25 \mu$ の範囲内で大きな傾斜と復元の振動をくり返した. 維持装置の離脱までに, 維持歯の沈下はほとんど認めら れなかったが, 維持力の発現に伴って維持歯に傾斜, 移 動などの動きがみられたものの, それは他の維持装置と 比較して非常に少なかった.

次に模型上の人工歯被験歯において, 口腔内と同じ維 持装置を用いて, 各維持装置をサーベィヤー上で牵引 し, その維持力発現時に人工被験歯に発生した動摇波形

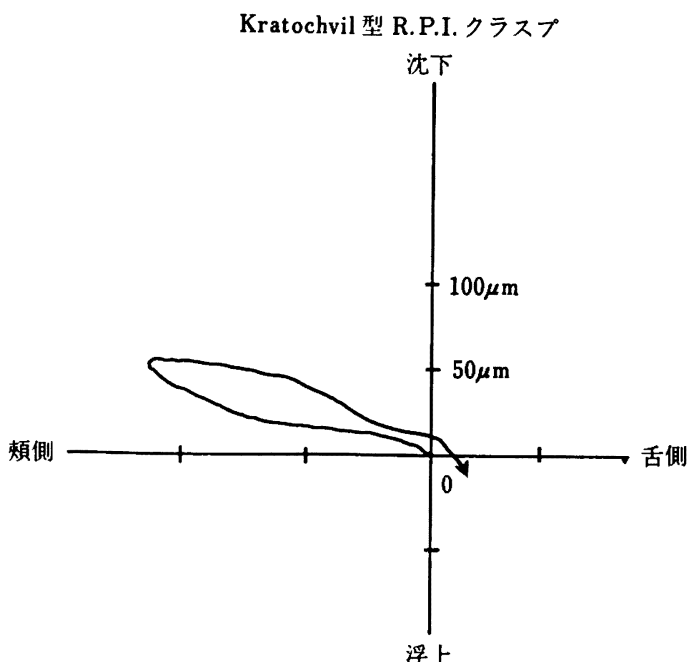

図 14 維持装置離脱時の維持歯の動摇量

(Kratochvil 型 R.P.I. クラスプ)
34 巻 3 号 (1990)

を同様に测定した結果，その波形と維持力は口腔内維持 歯で測定した場合と同様な傾向を示したが，模型上では その傾向がより単純で顕著に現れた。

\section{2. 離脱時の各維持装置が腔内と模型上の維持菌に 与えた動摇量の最大値とその時の維持力}

両者の測定結果から，各々の維持装置が維持歯に与え た各方向の動摇量の最大值を測定した. またその際の維 持力を測定した（表 1，2）.

1）鋳造レスト付き 2 腕鉤

模型上では煩側方向へ約 $80 \mu$, 舌側方向一約 $11 \mu$ と 㛲側方向では口腔内より小さな值を示したが，舌側方向

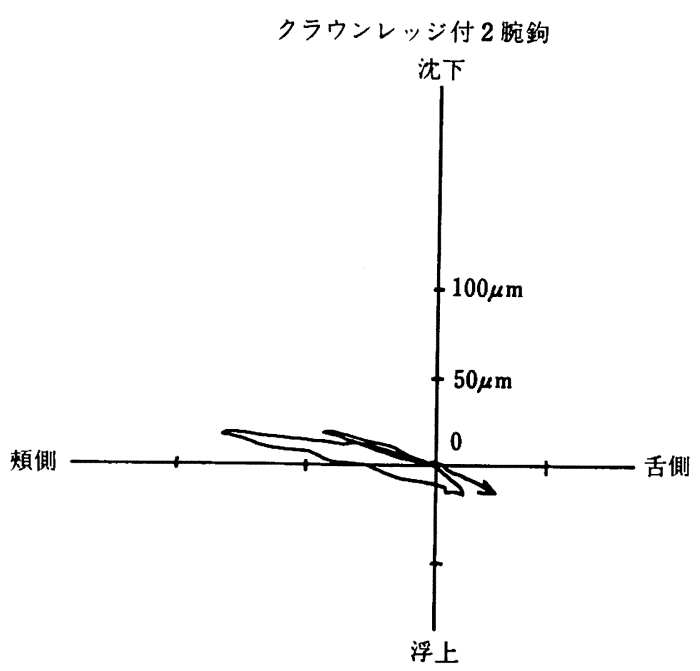

図 15 維持装置潅脱時の維持歯の動摇量

（クラウンレッジ付き 2 腕鉤）

表 1 各維持装置が維持歯に与えた各方向の最大動摇量の平均值と標準偏差

\begin{tabular}{|c|c|c|c|c|c|}
\hline & 煩側方向 & 舌側方向 & 沈下方向 & 浮上方向 & 維 持力 \\
\hline $\begin{array}{ll}\text { 被 } & \text { 験 } \\
\text { 動 摇 量 }\end{array}$ & $\begin{array}{r}245.7 \\
(\quad 3.8)\end{array}$ & $\begin{array}{c}34.4 \\
(5.4)\end{array}$ & $\begin{array}{c}109.1 \\
(\quad 6.3)\end{array}$ & $\begin{array}{c}14.6 \\
(0.5)\end{array}$ & $\begin{array}{l}500 \mathrm{~g} \text { で } \\
\text { 各々荷重 }\end{array}$ \\
\hline $\begin{array}{l}\text { レスト付き } \\
2 \text { 腕 鉤 }\end{array}$ & $\begin{array}{c}125.4 \\
(48.4)\end{array}$ & $\begin{array}{c}0 \\
(0)\end{array}$ & $\begin{array}{c}44.5 \\
(35.8)\end{array}$ & $\begin{array}{c}11.6 \\
(5.2)\end{array}$ & $\begin{array}{l}732.4 \mathrm{~g} \\
(207.0)\end{array}$ \\
\hline $\begin{array}{l}\text { Krol } \\
\text { R.P.I. }\end{array}$ & $\begin{array}{c}59.7 \\
(16.6)\end{array}$ & $\begin{array}{c}11.8 \\
(1.8)\end{array}$ & $\begin{array}{c}71.5 \\
(61.9)\end{array}$ & $\begin{array}{c}28.4 \\
(9.0)\end{array}$ & $\begin{array}{c}325.6 \mathrm{~g} \\
(64.0)\end{array}$ \\
\hline $\begin{array}{c}\text { Kratochvil } \\
\text { R.P.I. }\end{array}$ & $\begin{array}{c}122.3 \\
(33.9)\end{array}$ & $\begin{array}{c}0 \\
(0)\end{array}$ & $\begin{array}{c}34.1 \\
(10.0)\end{array}$ & $\begin{array}{c}14.2 \\
(8.2)\end{array}$ & $\begin{array}{c}340.3 \mathrm{~g} \\
(78.0)\end{array}$ \\
\hline $\begin{array}{c}\text { クラウン } \\
\text { レッジ }\end{array}$ & $\begin{array}{c}103.7 \\
(47.4)\end{array}$ & $\begin{array}{c}0 \\
(0)\end{array}$ & $\begin{array}{c}37.9 \\
(26.5)\end{array}$ & $\begin{array}{c}21.8 \\
(14.7)\end{array}$ & $\begin{array}{l}845.0 \mathrm{~g} \\
(272.2)\end{array}$ \\
\hline
\end{tabular}


表 2 各維持装圆が模型上で示した各方向の最大動摇量の平均值と標準偏差

\begin{tabular}{c|c|c|c|c|c}
\hline \hline & 頼側方向 & 舌側方向 & 沈下方向 & 浮上方向 & 維 持 力 \\
\hline $\begin{array}{c}\text { 人 エ 歯 } \\
\text { 動 摇 量 }\end{array}$ & $\begin{array}{c}361.7 \\
(7.8)\end{array}$ & $\begin{array}{c}117.1 \\
(3.7)\end{array}$ & $\begin{array}{c}85.2 \\
(10.5)\end{array}$ & $\begin{array}{c}105.0 \\
(12.9)\end{array}$ & $\begin{array}{c}500 \mathrm{~g} \text { で } \\
\text { 各々荷重 }\end{array}$ \\
\hline $\begin{array}{c}\text { レスト付き } \\
2 \text { 腕 鉤 }\end{array}$ & $\begin{array}{c}(30.4 \\
(37.3)\end{array}$ & $\begin{array}{c}11.6 \\
(6.7)\end{array}$ & $\begin{array}{c}0 \\
(0)\end{array}$ & $\begin{array}{c}72.5 \\
(35.0)\end{array}$ & $\begin{array}{c}497.8 \mathrm{~g} \\
(93.5)\end{array}$ \\
\hline Krol & 317.8 & 6.4 & 134.1 & 32.5 & $202.3 \mathrm{~g}$ \\
R.P.I. & $(80.9)$ & $(0)$ & $(4.4)$ & $(2.5)$ & $(24.2)$ \\
\hline Kratochvil & 12.2 & 13.7 & 0 & 22.5 & $602.8 \mathrm{~g}$ \\
R.P.I. & $(8.5)$ & $(2.3)$ & $(0)$ & $(6.4)$ & $(191.9)$ \\
\hline クラウン & 185.1 & 0 & 0 & 112.2 & $611.3 \mathrm{~g}$ \\
レッジ & $(54.4)$ & $(0)$ & $(0)$ & $(33.3)$ & $(91.1)$ \\
\hline
\end{tabular}

単位 $: \mu$

( )：標準偏差

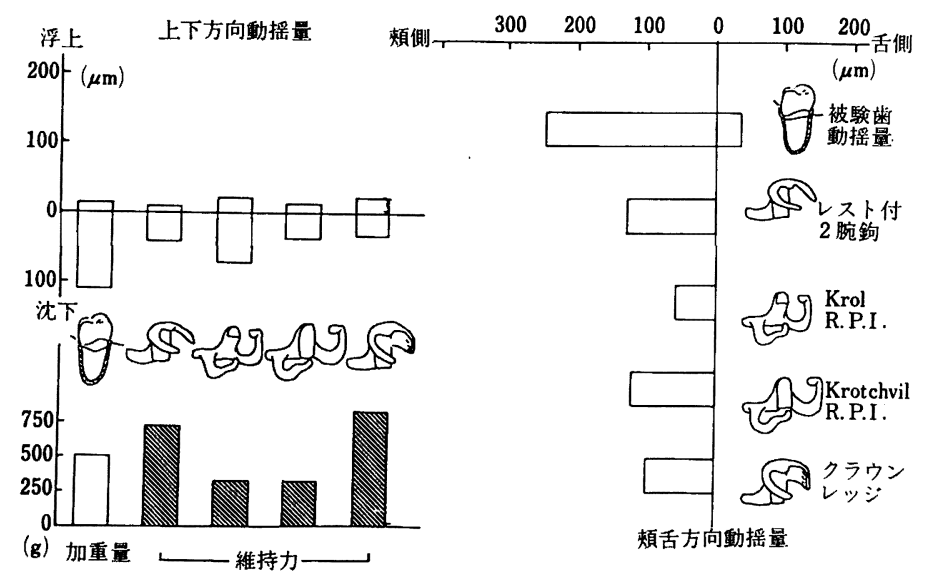

図 16 各維持装置を用いたときの維持歯の動摇量（被験者）

では模型上の方が大きな値を示した．維持力は口腔内と 比較して小さく前者の約 $730 \mathrm{~g}$ から約 $500 \mathrm{~g}$ に減少し た.

\section{2）クロール R.P.I. 型クラスプ}

模型上の頓側方向の動摇は口腔内より大きく約 $320 \mu$ の値を示した. 維持力は小さな值を示したが，特に模型 上では約 $200 \mathrm{~g}$ と最も小さい值を示した.

3）クロトビル R.P.I. 型クラスプ

口腔内では模型上とは異なり, 煩側方向に約 $120 \mu$ と 大きな動摇を示した. 維持力は口腔内で約 $340 \mathrm{~g}$, 模型 上で約 $600 \mathrm{~g}$ を示した.

4) クラウンレッジ

賽側方向に口腔内で約 $100 \mu$, 模型上で約 $185 \mu$ 動摇 した. 維持力は大きく, 口腔内で約 $840 \mathrm{~g}$, 模型上で約 $610 \mathrm{~g}$ を示した.
齿の生理的な動摇量を測定する際，通常被験者が不快 感を抱かない外力として $500 \mathrm{~g}$ を荷重する際の動摇量が 指標として使用されている18). そこでここでも同じく $500 \mathrm{~g}$ の荷重量を加えた時に生じる口腔内維持歯の動摇 量と同様に，模型上人工歯根維持歯での動摇 量を計測 し，その值を表に示した. 今回測定に用いたすべての維 持装置により, 離脱時両維持歯に与えた動摇量は, $500 \mathrm{~g}$ 荷重時に生じた動摇範囲よりも小さな值を示したことと なった.

これらの結果をグラフにして示した（図 16，17）.

$$
\text { IV. 考察 }
$$

維持歯は，部分床義歯装着時間の経過とともに㖣失が 一般に多くなる．これは歯周疾患の問題に加えて義歯装 


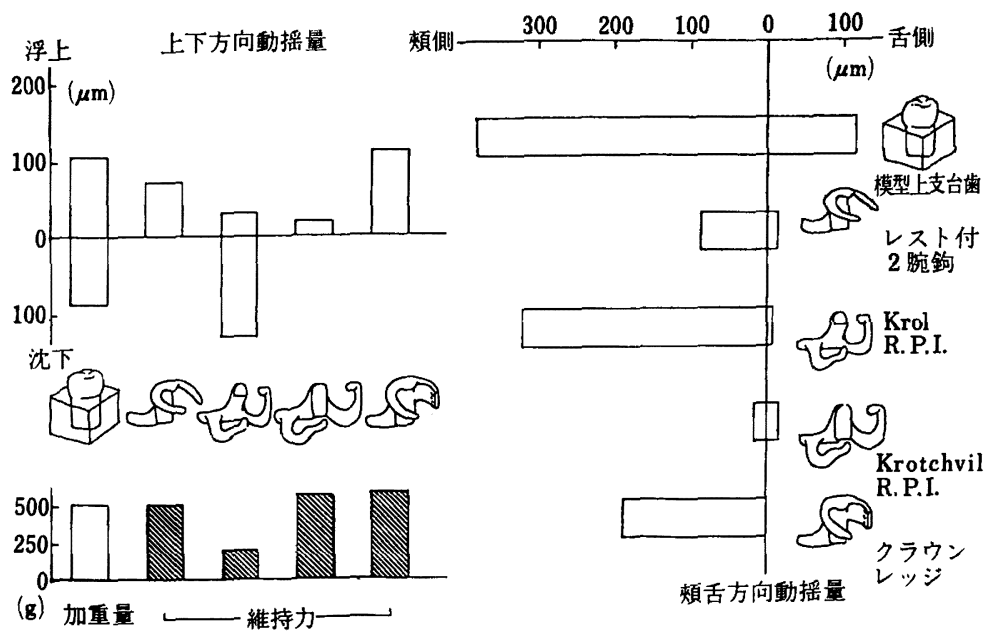

図 17 各維持装置を用いたときの維持歯の動摇量（模型上）

着によって，種々な負荷が維持歯に蓄積的に加わること が大きな原因である，その対策として，K. Körber ${ }^{19 \sim 21), ~}$

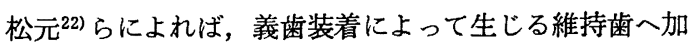
わる種々の負荷を歯根の持つ生理的な負担能力の範囲内 に収めることが必要であると報告されている.

通常, 歯は上方からの荷重にたいしては,かなり大きな 抵抗を示すが，一方水平方向および毫引方向の力に対し ては弱く，これらの力が複合的に作用すると経時的には 歯根の毫引作用を為すといわれている ${ }^{23)}$. 実際の部分床 義歯装着による機能時, 離脱時の一連の義歯の運動過程 では，この為害性の高い毫引方向の力のほとんどが維持 歯に集中的に作用していると考えられる. 維持歯への負 荷に関する研究では, 各々のクラスプが維持歯へどの程 度の負荷を与えているかについて, Mühleman ${ }^{11)}$, Körber ${ }^{24)}$ によって模型上および口腔内で義歯を装着して歯 の動摇量の変化を計測し報告しているが, 各種維持装置 の違いによる維持歯の離脱方向に加わる負荷と, 動摇量 の変化の関係についての報告は皆無に等しい.

そこで筆者は，まず離脱時に 5 種類の維持装置（鋳造 2 腕鉤 2 種, 屈曲 2 腕鉤, R.P.I. クラスプとコーヌスク ローネ) を用いて部分床義歯維持装置が維持歯に与える 動摇量を被験者と模型上の両方で計測した結果, コーヌ スクローネが維持歯に与えた動摇量が最も小さく，健全 歯根の生理的耐性範囲内といわれる各方向 $500 \mathrm{~g}$ 荷重時 の動摇範囲内に収まることを報告した ${ }^{12)}$. しかし，この 報告では 1 回ずつの離脱時に生じる維持歯の動摇量の大 小は判明したが，長期的に義歯を使用した場合にみられ る維持歯の負荷についてまでは解明することができなか った. そこで, 次に部分床義歯を長期間使用したときの
維持装置による維持歯への為害性の蓄積効果についての 検索を行った. 被験者 1 名を用い， 3 種類の維持装置 （鋳造 2 腕鉤，アタッチメントとコーヌスクローネ）を 選定し, 各々一定期間ずつ装着し，各期間毎の維持歯に 加わった為害作用の蓄積効果をその維持歯の動摇量の変 化を指標として測定した. コーヌスクローネ以外の維持 装置の装着後, 測定した被験維持歯の動摇量は, コーヌ スクローネを装着していた期間後に示した維持歯の動摇 量と比較して大きいことがわかった。 またコーヌスクロ 一ネは維持歯を保定, 安静させたのちに維持歯が示した 動摇量とほぼ同様の值しか示さなかった. この結果によ りコーヌスクローネは, 維持歯に与える蓄積的疲労が少 ない維持装置であることが示唆された ${ }^{13)}$.

これら一連の研究によりコーヌスクローネの有効性を 示した. この理由としてはコーヌスクローネの維持力の 発生機構の特殊性, つまり内外冠の厥合時適合性の良好 さと把持効果の強さ, さらに離脱時に側方力をほとんど 発生しないことに起因しているものと考えられる. しか しながらこのような利点を持つコーヌスクローネに対 して, 実際の臨床においては製法の簡便性などの点か ら，クラスプを主体とした維持装置の部分床義歯が頻用 されている. そこで，クラスプにコーヌスクローネの特 性を発揮させていると考えられるガイド面を多用するこ とにより，その特性をクラスプに兼ねそなえることが出 来るのではないかと考え, 現在臨床に広く用いられてい るクラスプ維持装置の中でガイド面機構を有するものを 選定し，それらの維持装置が離脱時に維持齿に与える動 摇量を測定し，種々の異なるガイド面により，維持歯に 生じる動摇量がどのように変化するかについて調べ，ま 
たその有効性の検討を行った.

本実験も以前の報告と同様に ${ }^{12,13)}$ ，維持歯に加わる負 荷が大きいと思われる下䫛片側遊離端義苗症例とし，通 法の義歯設計に従い反対側に間接維持装置を設定し，バ 一で連結する設計とした．測定にはガイド面を有する 4 種類の維持装置を使用したが，測定に際して義崡床など の維持装置以外の部分が測定結果に影響を与えない構造 とし，離脱時に維持装置が与える動摇のみを測定するた め左右の両維持装置部分を直接連結し，かつ全体を平行 に離脱が出来るように製作した，そして，この維持装置 の離脱時の被験歯の動摇量と維持力との関係を調べた.

その結果，鉱造レスト付き 2 腕鉤では，維持歯は維持 力発現中, 微細な振動を示しながら煩側方向人大きく傾 斜した曲線を持つ二重構造の波形を示した. またこの際 維持蒾は少し沈下を示した. この傾向は模型上の測定で も程度は小さいが認められた。これらの維持歯の沈下 は, 測定用ターゲットと維持歯との間に距離があるため に, 維持歯が傾斜し移動を示した結果が沈下したような 軌跡となって現れたと考えられる. 一般に 2 腕鉤では維 持装置を牽引していくと， 2 腕銁の銁先が維持歯全体を 弾力的に取り囲んでいるため, 表面に密着している $2 つ$ の鈎先が離開し，その際銁自体の金属が持つ弾性によっ て変形しながらクラスプが維持歯表面に沿って上昇して いき, 維持力が発現すると考えられている ${ }^{25)}$. しかし, 本実験では, 維持歯は傾斜や移動を示した上に, 特徴的 なのは波形が二重構造を示した点である．つまり大きな 波形は鈎先の離開による鉤自体の金属の持つ弾性により 生じ, これにより離脱の際に煩舌側の鈎の弾性の違いに より維持歯の他方向への移動をもたらし，細かな波形は 歯表面の細かな凹凸と鉤の摩擦により生じたものであ る. 維持歯はこれら 2 種類の力に対して維持歯が抵抗す ることにより,維持装置から発現していると判断した. た，被験維持歯および模型上の測定結果が共に煩側に大 きく摇り動かされた結果を示したことから， 2 腕鉤の両 鈎先が維持歯のアンダーカットにあるときは，2つのう ち強く作用している方の鉤先と反対方向に維持歯が動か

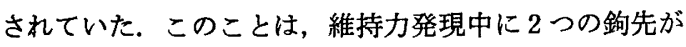
いつも密着し絶えず金属の理想的な弾性を示しながら, 維持歯を包むように維持力を発揮するのが非常に難しい ことを示している.また実際に鉤の維持力は歯冠形態の 左右非対称性および製作上の困難さにより, 維持力の発 現中に作用しているのはいずれか一方の鉤先が他方に比 較して強く作用して拉り，その際他方の鈎先はそれに対 して維持歯の動きを押さえるガイド的な作用しかしてい
ないものと考えられる. さらに, これらの他に維持歯に 為害性を与えていると思われるものとして, 鉤先が維持 歯表面に与えている微細な振動がある.これは銁と冠の 両者間で理想的には滑走運動が起こっていないことを示 していると判断した. そしてこの微細振動は, 維持歯の 維持装置離脱までの歯自体の振動量を総和的に大きくす る作用を示しており，これが離脱力に加わり 2 腕鈎の為 害性を高める原因となっていると考えられた. クロール R.P.I. クラスプが維持力発現中, 維持歯が示した動摇は, I バーの先端部が維持歯の煩側豊隆部の下に接触してお り，豊隆部を下部から押し上げるように作用しているた め, 維持歯は反対側の舌側方向から煩側上方へ引っ張り 上げられたような動きを示した.この動きは，遠心隣接 面板及び近心の舌側レストなどのガイド作用の影響と考 えられる，すなわち，維持装置と維持歯間の摩擦作用で 維持歯自体を持ち上げるように作用しているためと思わ れる.この結果は, 歯軸と着脱方向をより一致させやす い模型上において一層顕著に認められた.

I バーの維持力は，バーの先端の金属自体の弾性によ ってその維持力を発現しているが，その維持力は全体の 維持力の中では小さく, 舌側のレスト, 遠心の隣接面板 と維持歯との間に存在する摩擦力の方が大きいため, 維 持装置離脱に従って維持歯が I バーの先端を中心として 煩側へ傾斜したのち，離脱しているような運動をしたも のと考えられる.

クロトビル R.P.I. クラスプの維持歯の動摇傾向は, ク ロール R.P.I. とほぼ同様の波形傾向を示した.これは両 者の維持力発現機構が類似しているためと考えられる. クロトビル型の全体的な動摇波形はクロール型に比べて 稳やかで，全体には，微細な振動を示しながら大きく振 動をする二重構造を示した. この二重構造は模型上の測 定結果でも同様な大小 2 種類の振動を示した.

クロトビル型がクロール型と比較して, 動摇波形が小 さいのは, 維持装置の離脱の際に維持歯を金属面でガイ ドする要素が大きいためで，反面その誘導により微細な 振動波形を生じていると思われる.

維持装置のガイド面要素が多くなると，それらの金属 接触面積とその接触時間の接触総和が大きくなることか ら維持歯の動きは規制され，維持歯は大きな動摇を示さ なくなるが,一方ガイド機構と維持歯との間の摩擦によ る細かい運動が出現する傾向が認められた.

両 R.P.I. クラスプとも, 離脱時に維持歯に与える動摇 は, 離脱までに煩側に維持歯を大きく一度振動させてい て, その振幅は 2 腕鈎と同程度で比較的大きな值を示し 
$10-436$

たが, その動摇全体の波形は単純な曲線であった。これ はクロトビルやクロールが, 義歯機能時に近遠心方向に

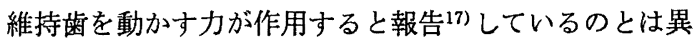
なった結果を示した. また模型上でも同様に煩側に振れ た軌跡を示した.これは本実験では日常臨床で行う義歯 の設計と同様に，構成要素には反対側に間接維持装置を 組合せて，義歯の着脱方向を規制する要素を含ませたこ とに起因していると思われる. この両 R.P.I. クラスプ の振動波形が大きく単純なのは, 両維持装置がその維持 力を瞬時に解放する機構になっているためと思われる.

しかし, この両維持装置が維持力発現中に維持歯に与 えた動きは, 維持歯に大きな傾斜, 移動を与えるむので ありこれは両 R.P.I. クラスプが維持歯から離れる時 に維持歯の動摇が単純化せず，一般にいわれている程 R.P.I. クラスプが有効に働いていないことを示している と思われる。

クラウンレッジクラスプの場合は門井 ${ }^{28)}$ が報告してい るように，舌側にあるガイド面が舌側方向への動きをす べて規制している.これに対し煩側方向へは鈎先が維持 歯の表面を移動する際, 生じる摩擦によって維持歯に動 摇を与え, 舌側のガイド面から煩側方向へ, 鈎先の移動 に従って, 振動が生じた. しかし, この際少々支台歯が 沈下した軌跡を示したが，これも維持歯とターゲットと の微妙な距離の差によって生じたと考えられ，その值は クラスプに比べて小さかった. 模型上の結果も同様な傾 向を示した. 今回維持歯は維持力発現中は舌側のガイド 面によって把持され, 維持蒾は移動および回転などの運 動を起こしていなかった. そしてこの煩側方向への動摇 傾向は模型上でより顕著に現れた. これはこの維持装置 の維持力発現機構の特色で, 煩側の 1 つの鉤先によって 生じた大きな煩舌両方向への振動を示しており，その振 動は 2 腕鈎のときと同様に鈎先が維持歯表面との摩擦作 用によって生じた微細な振動を示した. しかし,その全体 の動きは舌側のガイド面によって規制されているため, クラスプはその理論に近い働きをして維持力を発揮して いる結果を得た.すべての測定結果において, 模型上の 波形は口腔内と比較して整った波形を示した. これは,

1. 口腔内の維持歯の植立方向と実際の維持装置の着 脱 方向との差異, 2. 口腔内では測定装置を垂直方向に正し く牽引することの困難さ, 3 . 鈎先の滑走の様相が冠表面 の濡れなどによって摩擦傾向が微妙に異なることなどが 考えられる. 今回測定した両側性と直接および間接維持 装置を持った 4 種類の測定維持装置は，それぞれ異なっ たガイド面機構を有しているが, 離脱時に, 維持歯の生
34 巻 3 号 (1990)

理的な動摇範囲を逸脱する動摇は与えていないことか ら，これら 4 種の維持装置は非為害的であることが示唆 された。

これら 4 種の維持装置のうち, 維持歯に与える為害性 の評価では, クラウンレッジが，維持歯の沈下および移 動をほとんど生じさせず，その煩舌方向の動摇も一定範 囲内であったことから，最も為害性の少ない維持装置で あると考えられた。

今日まで, 部分床義歯による運動時の維持歯に作用す る力の解析は，ただ単に義歯上に加わった力を幾何学的 に分析して，その維持装置の有効性を論してきている7). ところが今回実際の口腔内で種々の維持装置本体のみを 用いて維持歯へ伝達される力を維持歯の動摇によって計 測したところ, 水平, 垂直各方向に複雑な動摇を与えて いることが判明し，義歯装着により維持歯は今まで考え られてきた幾何学的な力学解析以上の負荷を受けている ことが示唆された.

したがって,これら維持歯への為害作用を極力おさえ るためには, 維持力発生の過程で生じる種々の動きとそ の維持力作用時間を極力少なくし, そして維持歯が持つ 生理的許容動摇範囲内に收めることが必須であることが 解明された. そのためにはガイド面の有効性を考慮にい れた上で, 維持歯に出来る限り単純な動摇のみを与え, かつその作用時間の短い維持装置を選定することが重要 であることが示唆された.

\section{V. 結 論}

現在頻用されている部分床義歯の維持装置のうちで, ガイド機構を有する 4 種類の維持装置を用い, そのガイ ド面の有効性について検討する目的で，維持装置が離脱 時に与える負荷を維持歯の動摇量として, またその際の 維持力を測定した.

測定は口腔内維持歯とそれと同様な欠損型式を有する 疑似模型の維持歯との両者で同一の装置を用いて行い， 次の結論を得た。

1. クラスプ維持装置は, 維持力の発現に伴い維持歯 に多方向の微細運動を与えた. これは維持歯に為害作用 を与えていると判断された.

2. 両 R.P.I. 維持装置は, 維持歯の歯軸と義歯着脱方 向が一致した場合の動摇量は小さく, 維持力む適切で為 害性は小さかった. しかし歯軸と着脱方向を一致させる ことは困難で, 動摇防止, 維持力の適性化が難しいこと が判明した。 
3. クラウンレッジの舌側ガイドプレーンは, 維持歯 の動摇を抑制する効果があった.

4. 測定に用いた 4 種の維持装置が離脱時に維 持 歯 に，生じさせた負荷を動摇量でみてみると，ガイド機構 の付与によりその動摇量は, 維持歯の生理的な動摇範囲 内に収まることがわかり，その為害性は少ないことがわ かった.

稿を終えるに臨んで，終始ご想篤なご指導とご校閲を賜りま した芝爟彦教授に深甚なる感謝の意を表します。また常に親 切多大なるご指導を戴きました五十嵐順正助教授に深謝致しま す.また本研究に理解を示され実験に協力してくださいました 第 3 補経学教室の方々に心より感謝致します.

本論文の要旨の一部は、第 75 回日本補経歯科学会学術大会, 第 77 回日本補経歯科学術大会, 第 80 回日本補緅菌科学会学術 大会, 第 7 回昭和歯学会総会において発表した.

\section{文献}

1）尾花甚一, 水野克弥, 地挽英彦ほか: 部分床義歯の予後に 関する臨床的研究, 第 4 報鈎歯の動摇について, 補経誌, $7: 148 \sim 155,1963$.

2) Goto, T.: Changes in abutment tooth mobility by wearing partial denture, Bull Tokyo Med Dent Univ, $17: 329 \sim 343,1970$.

3) Körber, E., Lehman, K. und Pangidis, C. : Kontrolluntersungen an parodontal und parodontal-gingival gelagerten Teilprothesen, DZZ, $30: 77,1975$.

4）真鍋 顕：アタッチメント義齿の予後関する臨床的研 究, 補経誌, $20: 156 \sim 172,1976$.

5）松元 誠：遊離端義歯, 96, 医歯薬出版, 東京, 1976.

6) 松元 誠: 遊離端義歯, 89, 医菌薬出版, 東京, 1976.

7）関根 弘：パーシャルデンチャーと支台歯の負担軽诚, 尾 花甚一ほか, パーシャルデンチャーの臨床, 155 163, 医 菌薬出版, 東京, 1980 .

8）藍 稔: パーシャル・デンチャーの設計関する考え方 の変要, 後藤忠正ほが編, リジッド・サポートによるパーシ ヤルデンチャーの設計指針, 11, 医歯薬出版, 東京, 1987.

9) Bazirgan, M. and Bates, J.F. : Preliminary study of a method of measuring removable partial denture abutment tooth movement in vitro and in vivo, J Prosthet Dent, 56 : 204 207, 1986.
10) Steffel, V.L. : Fundamental principles involved in partial denture design, J Am Dent Assoc, $42: 534 \sim 544$, 1951.

11) Mühleman, H.R. : 10 Years of Tooth-Mobility Measurements, J Periodontol, $31: 110 \sim 122,1960$.

12）八川昌人，五十風順正，芝 燁彦：部分床義歯の着脱時に 維持菌が受ける負荷 (第 1 報)，昭和歯誌， $7: 104 \sim 114$, 1987.

13）八川昌人，五十嵐順正，芝 苹彦：部分床義崡の着脱時に 維持歯が受ける負荷 (第 2 報), 昭和歯誌, $8: 105 \sim 113$, 1988.

14）後藤忠正，加藤光雄：リジッドサポートとは，後藤忠正ほ か編、リジッドサポートによるパーシャルデンチャーの設 計指針, 19 42, 医菌薬出版, 東京, 1987.

15) Kratochvil, F.J. : Removal Partial Denture Syllabus, 39 40, UCLA, Los Angels, 1968.

16）Krol, A.J. : クロール パーシャルデンチャーデザイン, 64 72, 医菊薬出版, 東京, 1976.

17) Stratton, R.J. : An Atlas of Removable Partial Denture Design, 27 30, Quintessence Publishing Co., Chicago, 1988.

18）五十嵐順正, 藍稔：支台歯に強く支持を求めた遊離端 義宷, 補緅誌, $26: 1014 \sim 1020,1982$.

19）Körber, K. : ケルバーの補緅学, 第一巻, 52 , クインテッ センス出版, 東京, 1982.

20） Körber, K. : ケルバーの補敍学, 第一巻, 338 340, クイ ンテッセンス出版, 東京, 1982 .

21) Körber, K. : Konuskronen, 80, Hüthig, Heidelberg, 1983.

22）松元 誠: 遊離端義歯, 89 95, 医歯薬出版, 東京, 1976.

23）河辺清治: 補緅䛦療・今日の課題, 96, 医歯莧出版, 東京, 1981.

24）Körber, K. : ケルバーの補緅学 第一巻, 352 355, クイン テッセンス出版, 東京, 1982.

25）三谷春保: 歯学生のパーシャルデンチャー, 267 269, 医 歯薬出版, 東京, 1979.

26) Kratochvil, F.J. : Removal Partial Denture Syllabus, 36 38, UCLA, Los Angels, 1968.

27）Krol, A.J. : クロール パーシャルデンチャーデザイン, $31 \sim 36$, 医歯薬出版, 東京, 1976.

28）門井 聡, 中井雅人, 高橋龍彦ほか: コンビネーションク ラスプの考え方と製作法, 補觧誌, $30: 512 \sim 513,1986$. 